\section{Sustainable Competitive Advantage: A Survey of Companies in Southern Brazil}

\author{
Julio Cesar Ferro de Guimarães ${ }^{\dagger}$ \\ Faculdade Meridional IMED \\ Eliana Andréa Severo $\Omega$ \\ Faculdade Meridional IMED \\ César Ricardo Maia de Vasconcelos ${ }^{¥}$ \\ Universidade Potiguar (UnP)
}

\section{ABSTRACT}

A Sustainable Competitive Advantage emerges as an important factor in the perception of value of goods and services, which should be considered as elements of competitive differentiation. This study aims at identifying the relationship between sustainable competitive advantage and organizational performance, as well as measuring the relationship of environmental sustainability and social responsibility as attributes of sustainable competitive advantage. In order to achieve that, a survey was carried out in 1496 different size companies and activity sectors in Brazil. For the data analysis and interpretation we used a structural equation modeling technique. The results indicate that the Sustainable Competitive Advantage construct is an important antecedent of organizational performance because it highlights fundamental attributes for organizations to achieve positive economic consequences. This research contributes to organizational management and to the scientific community with the provision of a framework that assists in the identification of relevant strategic resource features.

Keywords: Sustainable competitive advantage; Environmental sustainability; Social responsibility; Organizational performance; Structural equation modeling.

\section{INTRODUCTION}

Organizations are cast into a global environment with constant market turbulence, such as potential competitors, currency devaluation, increases in interest rates and currency fluctuations. Contemporary organizations seek to administer their resources to achieve an advantageous position in relation to competitors and, thus, remain competitive.

A competitive advantage is a constant pursuit of enterprises, because being in a privileged position, presenting unique features of services and/or products, raises and maintains this position in the industrial sector, considering the enterprise's relationships with other peers (PORTER, 1980; BARNEY, 1991a; 1991b; ARAUJO; PISANO; SHUEN, 2003). The Resource-Based View (RBV) stands out as a framework capable of analyzing the resources from the perspective of Sustainable Competitive Advantage (BARNEY, 1991b), which assists researchers and business managers in effective assessment of their resources. The RBV recommends that resources should have specific
Corresponding author:

${ }^{\dagger}$ PPGA - Faculdade Meridional IMED E-mail: juliocfguimaraes@yahoo.com.br ^ PPGA - Faculdade Meridional IMED E-mail: elianasevero2@hotmail.com

${ }^{¥}$ PPGA - Universidade Potiguar (UnP). E-mail: cesar.vasconcelos@terra.com.br

Received: 02/07/2016. Revised: 03/04/2016. Accepted: 03/17/2016

Published Online: 02/01/2017. 
attributes, which could promote the differentiation of the organization that is facing competition, thus obtaining a Sustainable Competitive Advantage (BARNEY, 1991b). Therefore, influential variables, such as environmental and social aspects, are omitted or ignored. Within this context, and in order to cover this gap in academic literature, this study aims at creating a theoretical framework which covers social and environmental attributes. A sample of 1496 firms was used to validate this framework in order to bring it closer to companies' realities.

In this scenario, environmental sustainability and social responsibility also emerge as attributes for a sustainable competitive advantage. Environmental practices contribute to the reduction of inputs used in production, better quality and lower production costs, as well as less environmental pollution (SEVERO et al., 2015). Also, social responsibility strategies are aimed at a better quality of life for employees, as well as the community as a whole.

A sustainable competitive advantage emerges as an important factor in the perception of goods and services value, which should be considered as elements of competitive advantage. From this context, the objective of this study is to identify the relationship between sustainable competitive advantage and organizational performance, as well as to measure the relationship between environmental sustainability and social responsibility as attributes of sustainable competitive advantage through a survey of 1496 companies of different sizes and segments in the state of Rio Grande do Sul (Brazil).

\section{RESEARCH HYPOTHESES}

\subsection{RESOURCE-BASED VIEW (RBV), ENVIRONMENTAL SUS- TAINABILITY AND SOCIAL RESPONSIBILITY}

The RBV is related to the accumulation of the valuable, rare, inimitable and nonsubstitutable resources, which are the basis of enterprise competitiveness and economic rent (BARNEY, 1991a; LIN; WU, 2014). Accordingly, resources are elements which are inherent to the company and generate value to the organization, which can only be transferred with costs and with which the organization is able to develop strategies to maintain or obtain a particular competitive market position (BARNEY 1991a, 1991b; BESANKO et. al., 2013). Strategic resources must present some attributes: Valuable Resources; Rare Resources; Imperfectly Imitable Resources; Strategically Irreplaceable (Durable) (BARNEY, 1991a; 1991b) in order to generate a sustainable competitive advantage for the company. As a complement, Peteraf (1993) requires that the resources must have tools to avoid their wearing out as time goes by, which refers to the resource capacity of owning an imperfect imitability and exchangeability. Makadok (2001) believes that strategic resources can influence other resources, increasing productivity by expanding an organization competitiveness.

Another important factor is the organization capacity to adapt to context changes, which is called by Teece, Pisano and Shuen (1997) as a dynamic capacity and which happens through resources and competencies interaction (both functional and organizational) in order to obtain competitive advantage. In this sense, Araujo, Dubois and Gadde (2003) highlight that performance and firm limits are influenced by the decisions over the way the organization relates to other peers in their environment. The contributions from Teece, Pisano and Shuen (1997) and Araujo, Dubois and Gadde (2003), widen Porter's (1980) and Barney's $(1991 \mathrm{a} ; 1991 \mathrm{~b})$ views as they show the dynamics of the relationships between resources, dynamic capacities, industry position and stakeholders.

In addition to being valuable, rare, inimitable and non-substitutable (BARNEY, 1991a, 1991b) and the premises from Peteraf (1993), Teece, Pisano and Shuen (1997) and 
BBR

14,3

Araujo, Dubois and Gadde (2003), strategic resources must also have characteristics that conform to environmental sustainability and social responsibility in order to improve the organization performance (LO; SHEU, 2007; MONEVA, LIRIO, TORRES, 2007; GHOUL et al., 2011; DE GUIMARÃES et al., 2014).

In literature, discussions regarding environmental sustainability consider mainly the aspects that encompass renewable natural resources, environmental impacts and environmental practices used by organizations (ROY; BOIRAL; LAGACÉ, 2001; KOLK, 2003; NIEMEIJER, 2004; SHARMA; HAGOS, 2005; GRI, 2013; SEVERO et al., 2015).

The performance indicators recommended by the Global Reporting Initiative (GRI, 2013), a pioneer in the world of sustainability reporting information and, currently, the most widely used sustainability report on the market, aim at describing the economic, environmental and social impacts, such as Triple Bottom Line (ELKINGTON, 1997), as a way to certify the sustainability of a company. Research from multinational companies show that environmental sustainability is an important factor for obtaining a higher performance, considering the potential of reducing costs and gains on the company's image (TUKKER, 2004; GONZÁLEZ-BENITO; GONZÁLEZ-BENITO, 2006; VAN BOMMEL, 2011; GOLINI; LONGONI; CAGLIANO, 2014).

Environmental sustainability is currently seen in organizations as an area that, in addition to dealing with environmental issues, can become a source of competitive advantages. This is because its principles are the use of environmental practices (SEVERO et al., 2015) that minimize waste and reduce inputs used in production, resulting in better productivity and, consequently, increased competitiveness and improved organizational performance. Another way to improve performance is by using social responsibility as an ally in shaping the organization image and as a motivator for people involved in the process with the firm. In this sense, Dorion et al. (2015) take into account that the improvement projects should consider the impacts on the various stakeholders for, with the involvement of different peers, it is possible to widen the internal team potentialities and promote intangible gains which contribute to the organization competitiveness.

Social responsibility has been constantly discussed in recent years, due to the various transformations that have been taking place in the business world; the theme is no longer only the government's responsibility and is now discussed by the companies. This is why it is understood as the organizational management's obligation to decide and take actions that improve social well-being, supporting the interests of society and the company as well (CARROLL, 1999; BAKER; NASER, 2000; KUASIRIKUN; SHERER, 2004; MONEVA, LIRIO, TORRES, 2007; ATTIG et al., 2013).

Once social responsibility initiatives have been put into action, it is necessary to ensure life quality for local populations, removing political and institutional obstacles to their social integration, ensuring their participation in development strategies and the maintenance of natural capital stock (AGRAWAL; 2001; EKINS et al., 2003).

When discussing the role of social responsibility organizations, Porter and Kramer (1999) state that added value is created through philanthropy by motivated, informed and passionate people who are responsible for their choice of culture, values, history and continuity of the actions of corporate social responsibility.

Adding ethical and socially responsible behavior to their abilities, organizations earn the respect of people and communities that are impacted by their activities, which leads society to recognize their attitudes. Accordingly, social responsibility is becoming an increasingly important factor for business success, which creates new prospects for building a world that is more prosperous and socially and economically fair (INSTITUTO ETHOS, 2013; AGAFONOW, 2014; LO; SHEU, 2007; GHOUL et al., 2011)

Some studies show that social responsibility is an important factor which generates organizational performance, considering the aspects of employee motivation, and improve 
the company's image ahead to stakeholders, but it does not guarantee an increase in market (ORLITZKY; SCHMIDT; RYNES, 2003; SURROCA; TRIBÓ; WADDOCK, 2010). The precepts of the RBV are key to obtaining competitive advantage. However, it is crucial that resources also present the attributes of environmental sustainability and social responsibility (GUIMARÃES et al., 2015). This premise is the theoretical basis for the following hypothesis:

H1: the attributes of environmental sustainability and social responsibility are contributing positively to the construct of sustainable competitive advantage.

\subsection{SUSTAINABLE COMPETITIVE ADVANTAGE AND ORGA- NIZATIONAL PERFORMANCE}

Because of the importance of Sustainable Competitive Advantage (SCA) to the long-term success of firms, the existing literature addresses its content as well as its sources, and the different types of strategies that may help companies achieve SCA (KIM et al., 2012). Literature distinguishes competitive advantage with respect to market-related strategies (external) (PORTER, 1980) and the internal capabilities of a company (BARNEY, 1991a; 1991b). Market strategies relate directly to managerial decisions positioning the company in the forefront of industry competitors, whereas the capacities are related to the resources that the company has to face in the competition. Supporting the different visions, Porter $(1980 ; 1991)$ and Caves (1984) highlight that a competitive advantage can be derived not only from specific resources but also from privileged market positions as well.

Although studies by Porter $(1980 ; 1991)$ and Barney $(1991 \mathrm{a} ; 1991 \mathrm{~b})$ show distinct approaches for obtaining competitive advantage, other authors conclude that these views do not have an excluding nature, like the Besanko et al. (2013) case, upon highlighting that the sustainability of a competitive advantage depends on the isolation mechanisms, which may be defined as factors that stop competitors from neutralizing a higher performance in a given company, and which can be obtained by innovation, organization evolution and the company's domestic environment (or industry position). As a contribution to the academic discussion, Araujo, Dubois and Gadde (2003) warn about the inter-organizational relationships, and Teece, Pisano and Shuen (1997) state that the resources may be turned into routines which power up the organization performance results, composed of dynamic capacities. Consistently, it is pointed out that there is some view complementariness (both internal and external) of sustainable competitive advantage.

For practical purposes, the sustainable competitive advantage must be translated into a higher performance compared to competitors. According to Paladino (2007), the organizational performance targets the quality and profitability of goods and services and the return on investments, as well as the reduction of operational costs, compounding the overall performance of the company against the competition. According to Neely, Gregory and Platts (2005), performance evaluation can be defined as the process of quantifying an action, in which the measurement is equated with quantification, and the action is understood as that which leads to performance.

The need to include non-financial measures to evaluate organizational performance originated with the organizations' needs to become competitive in a new context in which financial measures alone were no longer enough (CHENHALL; LANGFIELD-SMITH, 2007). In this context, the performance measure represents a way to understand an organization's performance. It deals with the need to use a combination of financial and nonfinancial indicators (GARENGO; BIAZZO; BITITCI, 2005; MERCHANT, 2006). One example is highlighted in Hogan and Coote (2014): the effect of innovative behaviors on organizational performance is more strongly positive than that of values supporting innovation. Consistently, the indicators must be constructed based on criteria which make them 
BBR

14,3

suitable for future analyses (SHAHIN; MAHBOD, 2007). Based on the literature, it was identified that sustainable competitive vantage influences organizational performance as stated in the following hypothesis:

H2: A sustainable competitive advantage is positively related to organizational performance.

The literature shows that there is evidence of differences in the results of competitive advantage when considering the size of the companies, based on the premise that larger companies have a more complex structure, which supports the development of competitive advantages, such as the innovativeness. The variable size of the company can be observed in studies of Traill and Meulenberg (2002), Avermaete et al. (2004) and Triguero, Córcoles and Cuerva (2013).

In this sense, this study presupposes that the impact on the relationship between sustainable competitive advantage and organizational performance can be influenced by moderating company size and industry, since this research was conducted with several different-sized companies (micro and small businesses - MSBs -, medium and large companies - MLCs) and in different industries (manufacturing industrial, commercial and services), which led to the development of hypotheses 3 and 4:

H3: Company size has a moderating effect on the relationship between sustainable competitive advantage and organizational performance.

H4: Company industry has a moderating effect on the relationship between sustainable competitive advantage and organizational performance.

Figure 1 represents the theoretical model which composes the three hypotheses of the research presented in the study.

\section{METHODOLOGY}

In this study, a survey was carried out with 1,496 companies of different sizes and in different industries in the State of Rio Grande do Sul (Brazil), aiming at identifying the relationship between sustainable competitive advantage and organizational performance, as well as measuring the relationship between environmental sustainability and social responsibility while attributes of sustainable competitive advantage. To meet the objective of this research, we used Structural Equation Modeling (SEM) that seeks to analyze the relationships between constructs based on the theoretical precepts supported in the literature.

Note that for the test of Hypothesis 3 (H3), two distinct groups were considered: Group 1: composed of micro enterprises (annual revenues up to $\mathrm{R} \$ 360,00$ ) and small companies (annual revenues between $\mathrm{R} \$ 360,00$ and $\mathrm{R} \$ 3.6$ million); Group 2: midsize enterprises (annual revenues between $\mathrm{R} \$ 3.6$ million and $\mathrm{R} \$ 300$ million) and large enterprises (annual revenues with more than R $\$ 300$ million). For the tests of Hypothesis 4 (H4), we used three groups related to the industry, in which direct choices of respondents were considered in relation to the options of the Manufacturing (MAN), Commercial (COM) or Services (SER) industries.

The survey was performed using the descriptive research method and with the application of questionnaires, which were drawn from academic research and practices of organizations (Table 1). The questionnaire was given to managers of enterprises (owners, Chief Executive Officer). The observable variables were presented within the text in the form of statements, with a degree of agreement or disagreement in a 5-point Likert scale: i) 1 - Strongly disagree; ii) 2 - I partially disagree; iii) 3 - Neither agree nor disagree; iv) 4 - I partially agree; and v) 5 - Completely agree. The questionnaire (Table 1) was based on studies and assumptions: i) Barney (1991a, 1991b) (VA1, RA2, II3, EI4); ii) Instituto Ethos (2013), GRI (2013) and Severo et al. (2015) (ES5, RS6); iii) Paladino (2007) (PO1, $\mathrm{PO} 2, \mathrm{PO} 3, \mathrm{PO} 4)$. 


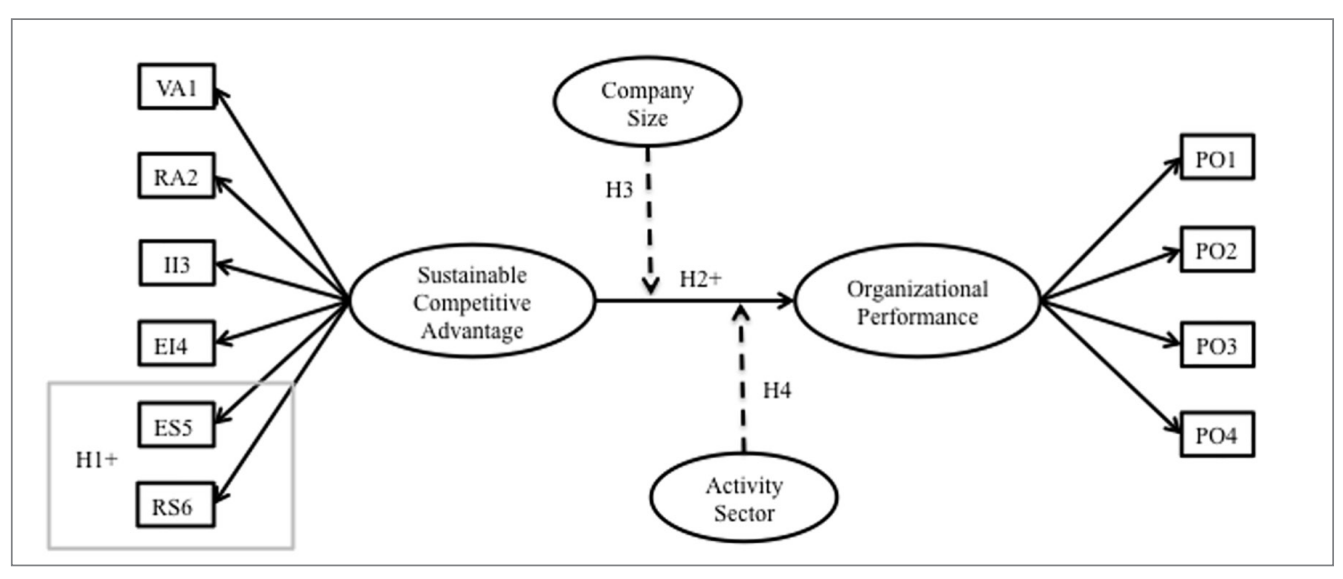

Figure 1. Model-proposed hypotheses.

Data collection occurred between the months of July 2014 and May 2015, obtained through personal contact, telephone and the Internet. Initially, a pre-test with 36 cases was given to business managers in order to validate the understanding of the questionnaire. Subsequently, the answers to the pre-tests were included in the survey data.

For data analysis, SEM uses a set of methodological statistical analysis procedures, enabling the testing of dependency relationships simultaneously and the measurement of the intensity of these relationships (HAIR Jr. et al., 2007; KLINE, 2005). SEM considered the sample size (n) as a minimum of 10 respondents for each observable variable (HAIR Jr. et al., 2007). This survey used 137 respondents, which contributes to Maximum Likelihood Estimation. Therefore, SEM obtained a total sample of 1,496 valid cases, above the recommended amount, which is at least 200 respondents (KLINE, 2005). In this data, missing values have not been identified. The sample is composed of different-sized companies located in the state of Rio Grande do Sul, Brazil. The selection of companies for the survey was random: taken from the organizations listed in the Federation of Industries of the state of Rio Grande do Sul (FIERGS, 2013), which has about 47,000 industrial companies and the Federation of the Commercial and Services of the state of Rio Grande do Sul (FECOMÉRCIO-RS, 2013), which has approximately 570,000 companies.

Tabulation and statistical treatment of data were performed using the SPSS ${ }^{\circledR}$ (Statistical Package for Social Sciences), Version 21, software for Windows ${ }^{\circledR}$ and SEM was applied with the use of AMOS software ${ }^{\circledR}$, Version 21, coupled with SPSS $₫$, which, according to Byrne (2010), present the functions required for the analysis that SEM demands. Confirmation of the proposed model (Figure 1) occurred with the use of Exploratory Factor Analysis (EFA) and Confirmatory Factor Analysis (CFA), to measure the relationship between the variables of each construct. Cronbach's Alpha was used to verify the combination of observable and latent variables (constructs) with an expected value over 0.7 (HAIR Jr. et al., 2007), to verify simple reliability of observable variables. Another analysis technique that we used was the Kurtose Index, in which each observable variable is evaluated through the Mardia's coefficient, with an expected value less than 5 (MARDIA, 1971).

EFA examined: i) the factorial charges, which represent the correlations between measured indicators and the latent variable, in which the accepted value is equal to or greater than 0.5; ii) Bartlett's Test of Sphericity and Kaiser-Meyer-Olkin Measure of Sampling Adequacy (KMO), with values above 0.5 , which gives viability to EFA; iii) the Communalities that must show factor loadings with values greater than 0.5 (HAIR Jr. et al., 2007); and, iv) multicollinearity, evaluated through Pearson's correlation coefficient, which is expected to be less than 0.8 . 


\section{RESULTS AND DISCUSSIONS}

Prior to the analysis, the data was debugged. This process identified and deleted 72 questionnaires that were considered outliers, as these contained responses focused on unique alternatives, showing inconsistency in relation to the rest of the data. The electronic form did not register the responses if a question was left unanswered. Thus, there were no cases of non-answers. At this research stage, the analysis sought to identify extreme scores, with univariate and multivariate outlier analysis (KLINE, 2005; HAIR Jr. et al., 2007), using $\mathrm{Z}$ score calculation for univariate, which did not identify cases with values greater than 3.3 for each variable. To identify multivariate outliers, the analysis applied the Mahalanobis calculation, which found no cases with a very large distance between the individual value and sample averages.

After data debugging, the analysis considered 1,496 cases valid, which present the following characteristics: $36.7 \%$ processing industries; $30.8 \%$ commercial; $32.5 \%$ services; $37 \%$ micro enterprises; $42.2 \%$ small businesses; $11.4 \%$ midsize enterprises; $9.4 \%$ large enterprises; $89.6 \%$ with social capital of Brazilian origin; 3\% multinationals; and 7.4\% mixed-capital companies (Brazilian and foreign capital).

Analysis of the theoretical model (Figure 1) started with implementation of EFA using Varimax rotation for the verification of the relationship between the variables of each construct, resulting in two main factors (Table 1), with $69.01 \%$ explanation of variability, with all factor loadings above 0.4 as recommended. The variable EI4 presented 0.417 of commonality, which is lower than the recommended value $(>0.5)$. However, we decided to keep it, due to the scientific importance of the composition of the sustainable competitive advantage construct.

The results of the Initial Integrated Model show the AVE of the constructs in Table 2 (SCA 0.737; OP 0.749), which should be greater than 0.7. The DV has a value of 0.300, which is less than the AVE, since the correlations between constructs (Discriminant Validity) should be less than the convergent validity (Average Variance Extracted). With the results of these indexes, we took the observable variables as consistent in their measurements.

To evaluate Hypothesis 1 (H1), which states that the attributes of environmental sustainability and social responsibility are contributing positively to the construct of sustainable competitive advantage, the factor loadings of these attributes were examined and presented the variable factors ES5 0.896 and RS6 0.897. In the case of EFA, with Varimax rotation, the variables ES5 and RS6 were grouped by SPSS in the same group as VA1, RA2, II3 and EI4 variables, totaling $39.69 \%$ of data variability explanation. These results show that the $\mathrm{H} 1$ hypothesis has been confirmed.

For the construct of Sustainable Competitive Advantage, the sample displays a Cronbach's Alpha of 0.875 , and for the Organizational Performance construct there was a Cronbach's Alpha of 0.859 , i.e. above 0.7 (HAIR Jr. et al., 2007), providing reliability to data sets. Bartlett's sphericity test proved to be significant and the measure of adequacy of KMO presented an index of 0.725 , demonstrating the feasibility of EFA. The Kurtosis index assessment, through the Mardia's coefficient, obtained values less than 5 (MARDIA, 1970; BENTLER, 1990), leading to the conclusion that there is normality of data, enhanced by the analysis of Pearson asymmetry coefficients, which resulted in values close to zero, indicating a moderate symmetry (KLINE, 2005; HAIR Jr. et al., 2007).

In the Pearson correlation analysis, the correlations between observable variables with values above 0.8 were not identified, and there was no multicollinearity among variables. With the validation of scales and constructs that articulate the theoretical model, the analysis of the integrated model (model of measurement and structural) was done to measure the relationships between constructs (Figure 1), considering the model's rates of adjustment and the statistical significance of the coefficients estimated, following the precepts of Kline (2005) and Hair Jr. et al. (2007). 
Table 1. Factor Loadings of observable variables - Varimax Rotation

\begin{tabular}{|c|c|c|c|}
\hline Observable Variables & $\begin{array}{l}\text { Factor } \\
\text { Loading }\end{array}$ & $\begin{array}{l}\text { Communa- } \\
\text { lities }\end{array}$ & Constructs \\
\hline $\begin{array}{l}\text { VA1) Valuable Resources: key resources represent value for } \\
\text { exploring market opportunities or assisting the organization in } \\
\text { defending itself against environmental threats through an incre- } \\
\text { ase in revenue and/or a reduction in spending. }\end{array}$ & 0.903 & 0.846 & \multirow{10}{*}{$\begin{array}{l}\text { Sustainable } \\
\text { Competitive } \\
\text { Advantage }\end{array}$} \\
\hline $\begin{array}{l}\text { RA2) Rare Resources: key resources are unavailable for other } \\
\text { organizations. These resources are very difficult for competitors } \\
\text { to acquire. }\end{array}$ & 0.699 & 0.498 & \\
\hline $\begin{array}{l}\text { II3) Imperfectly Imitable Resources: key resources are difficult } \\
\text { for competitors to imitate. }\end{array}$ & 0.744 & 0.588 & \\
\hline $\begin{array}{l}\text { EI4) Strategically Irreplaceable (Durable): key resources are } \\
\text { difficult to replace with another strategic equivalent. }\end{array}$ & 0.638 & 0.417 & \\
\hline $\begin{array}{l}\text { ES5) Environmental Sustainability: the company adheres to } \\
\text { environmental sustainability in the use of key resources in the } \\
\text { productive process and product development The company is } \\
\text { also committed to the well-being of workers, society and the } \\
\text { environment. }\end{array}$ & 0.896 & 0.825 & \\
\hline $\begin{array}{l}\text { RS6) The company responsibly uses key resources in terms of } \\
\text { the following aspects: economic (to provide society with goods } \\
\text { and services); legal (regarding legal premises); ethics (respect } \\
\text { for practices that are expected or prohibited by society); philan- } \\
\text { thropy (promote the well-being or quality of life of society). }\end{array}$ & 0.897 & 0.835 & \\
\hline $\begin{array}{l}\text { PO1) Our company's return on investment is larger than our } \\
\text { competitors'. }\end{array}$ & 0.814 & 0.691 & \\
\hline $\begin{array}{l}\text { PO2) Our company's return on its assets is larger than our com- } \\
\text { petitors'. }\end{array}$ & 0.801 & 0.674 & \\
\hline $\begin{array}{l}\text { PO3) The total operating costs of our company are less than the } \\
\text { total costs of our competitors. }\end{array}$ & 0.944 & 0.911 & \\
\hline $\begin{array}{l}\text { OP4) The overall performance of our company in the previous } \\
\text { year was better than our chief competitors'. }\end{array}$ & 0.776 & 0,612 & \\
\hline
\end{tabular}


Table 2. Convergent Validity and Discriminant Validity - Initial Integrated Model

\begin{tabular}{lcc}
\hline Constructs & SCA & OP \\
\hline $\begin{array}{l}\text { Sustainable Competitive Advantage (SCA) } \\
\text { Performance organizacional }\end{array}$ & $0.737^{\mathrm{a}}$ & \\
$\begin{array}{l}\text { Organizational Performance (OP) } \\
0.300^{\mathrm{b}}\end{array}$ & $0.749^{\mathrm{a}}$ \\
\hline${ }^{\mathrm{a}}$ Average Variance Extracted (AVE) - Convergent Validity (CV). & & \\
${ }^{\mathrm{b}}$ Correlation between constructs - Discriminant Validity (DV). & &
\end{tabular}

The measurement indexes and model adjustment model are used in the analysis to determine the degree in which the model measurement predicts the matrix of covariances. In this sense, the index that calculates the value of Chi-square $\left(\mathrm{X}^{2}\right)$ divided by the Degree of Freedom (DF) obtains a value of 22 in the Initial Integrated Model, which is above the threshold of 5.0 suggested by Tanaka (1993), showing that the model may not be suitable for this sample. However, this is not a criterion for the elimination of the integrated model, though it does suggest that it may undergo adjustments in order to fit the empirical data.

Table 5 shows that, for the Initial Integrated Model, the CFI indexes (0.866), NFI (0.861), AGFI (0.830) and GFI (0.895) resulted in lower values than the recommended value of 0.9 (Hair Jr. et al., 2007; Kline, 2005), reinforcing the model inadequacy. The RMSEA presents the value of 0.069 , which is within the limits suggested by Hair Jr. et al. (2007) and Kline (2005), between 0.05 and 0.08. The RMR presents the value of 0.800 and ECVI of 1.059, considered low values which were expected for this research, because Marôco (2010) recommends that the lower these values are, the better the adjustment of the integrated model is.

Additionally, the adjustment indexes and measurement model are presented in Table 5 (Figure 1), considering the variables of company size and industry of the surveyed companies. One can observe that these different groups have indexes (CFI, NFI, AGFI and GFI) with values close to the recommended amount (0.9) and the highervalued RMSEA of the Initial Integrated Model. These results support the inadequacy of the model, considering the moderating effect of company size and industry on companies. The indexes show the inadequacy of the integrated model. However, this does not invalidate the $\mathrm{H} 2$ hypothesis, which was validated in the hypothesis tests (Tables 3 and 4 ).

As a solution for improving indexes of measurement adjustments, the Final Integrated Model was developed (as shown in Figure 2), which kept the observable variables and admitted the correlation between some variables (VA1<-->RA2; VA1<->II3; VA1<-->EI4; EI4<-->ES5; II3<-->RS6). This correlation solution considers Valuable Resources (VA1) to be an important articulator between the attributes of Rare Resources (RA2), Imperfectly Imitable Resources (II3) and Strategically Irreplaceable (Durable) (EI4). It corroborates the findings of the research of Barney (1991b) and Makadok (2001) that analyzes the features and enhancing effects of interactions among resources, resulting in unique and distinctive capacities to generate competitive advantages. The correlation between attributes EI4 and Environmental Sustainability (ES5) is supported in surveys done by Elkington (1999), González-Benito and GonzálezBenito (2006), which introduced the interaction and the benefits of environmental sustainability. Consistently, the correlation between II3 and Social Responsibility (SR6) is based on arguments such as those found in studies by Porter and Kramer (1999) and Moneva, Lirio and Torres (2007), which warn about the distinct potential that comes as a result of the actions of corporate social responsibility. 
The Final Integrated Model presented results of significant relationships in hypothesis testing of covariance with increased values found, which are expressed in Table 6 ( $\mathrm{SC}=0.426 ; \mathrm{SD}=0.031 ; \mathrm{CR}=13,809)$. Correlation hypothesis testing of the Final Integrated Model presents significant results with an Estimate valued Coefficient (EC) of 0.422 , supporting the confirmation of the $\mathrm{H} 2$ hypothesis.

The adjustment indexes and measurement of the Final Integrated Model exhibit results with values higher than or close to the recommended value (CFI 0.937; NFI 0.932; AGFI 0.861; GFI 0.934). When compared to the Initial Integrated Model, the RMSEA (0.054), RMR (0.800) and ECVI (0.566) values demonstrate the adequacy of the model (Figure 2).

To test the moderating effects of company size and industry on the relationship between the sustainable competitive advantage and organizational performance constructs (Figure 1), we applied the SEM multi-group technique, dividing the sample into five groups: i) micro and small enterprises; ii) midsize and large enterprises; iii) industrial manufacturing; iv) commercial; v) services. In accordance with Byrne's (2010) recommendation, in the analysis of multigroup, all the paths in a model are fixed, except the path to be tested as different between the groups.

We conducted tests to verify the effect of moderating company size. Additionally, ANOVA was performed to check if the respondents displayed divergent behavior compared to groups of different-sized companies, showing that there is a significant difference between the respondents in groups (Difference $\mathrm{X}^{2}$ ), which confirms the H3 hypothesis. The results show that midsize and large enterprises have greater intensity ratios $(\mathrm{SC}=0.461 ; \mathrm{EC}=0.497)$ than micro and small enterprises $(\mathrm{SC}=0.400 ; \mathrm{SC}=0.373)$.

The moderating effect of business enterprise industry, which presents a significant difference between the groups of respondents (Difference $\mathrm{X}^{2}$ ), and was proven by ANOVA, confirms the $\mathrm{H} 4$ hypothesis. The results show that the service sector has greater intensity ratios $(\mathrm{SC}=0.548 ; \mathrm{EC}=0.498)$ than industrial manufacturing $(\mathrm{SC}=0.442 ; \mathrm{EC}=0.456)$ and commercial $(\mathrm{SC}=0.305 ; \mathrm{EC}=0.277)$.

Analysis of the final integrated model and the models that consider the effects of company size and industry moderation showed the results of the factor loadings of the observable variables (EFA), the validity and reliability of variables (KMO, AVE, Composite Reliability, Cronbach's Alpha), as well as the adjustment model indexes (CFI, NFI, AGFI, GFI, RMSEA, RMR, ECVI), which work as support for stating that the $\mathrm{H} 1, \mathrm{H} 2$ and $\mathrm{H} 3$ hypotheses have been confirmed and the relationships which were highlighted in the final model (Figure 2) are in accordance with this research. These results also show they are statistically significant.

\section{FINAL CONSIDERATIONS}

This research enabled the identification of relationships between the Sustainable Competitive Advantage (SCA) and the Organizational Performance (OP), as well as the measurement of the relationship between the Environmental Sustainability (ES) and the Social Responsibility (SR), while SCA attributes, through a survey carried out in different enterprises in different economy sectors, analyzed by the Structural Equation Modeling methodology. Among the findings in the research, we point out that SCA influences OP positively with the support of strategy resources ownership, just like ES and SR are part of the SCA attributes (Valuable Resources; Rare Resources; Imperfectly Imitable Resources; Strategically Irreplaceable - Durable), and which can be seen through this research's results.

The results show that the Sustainable Competitive Advantage construct is an important antecedent of Organizational Performance, because this shows fundamental attributes that organizations need to achieve positive economic consequences. In this 
Table 3. Hypothesis test (covariance) - Initial Integrated Model

14,3

\begin{tabular}{|c|c|c|c|c|c|c|}
\hline Constructs & & & $\begin{array}{c}\text { Standardized } \\
\text { Coefficient (SC) }\end{array}$ & $\begin{array}{l}\text { Standard De- } \\
\text { viation (SD) }\end{array}$ & Critical Ratio(CR) & $\mathrm{p}$ \\
\hline $\begin{array}{l}\text { Organizational } \\
\text { Performance }\end{array}$ & $<---$ & $\begin{array}{c}\text { Sustainable } \\
\text { Competitive } \\
\text { Advantage }\end{array}$ & 0.278 & 0.025 & 11.227 & $* * *$ \\
\hline
\end{tabular}

*** Significance level $\mathrm{p}<0.001$.

Table 4. Hypothesis test (correlation) - Initial Integrated Model

\begin{tabular}{lccc}
\hline Constructs & & Estimate Coefficient $(\mathrm{EC})^{*}$ \\
\hline Organizational Performance & $<---$ & Sustainable Competitive Advantage & 0,300
\end{tabular}

* Significance level $\mathrm{p}<0.001$.

Table 5. Adjustment index of the proposed model

\begin{tabular}{|c|c|c|c|c|c|c|c|}
\hline \multirow[b]{2}{*}{ Index } & \multicolumn{2}{|c|}{ Integrated Model } & \multicolumn{2}{|c|}{ Company Size } & \multicolumn{3}{|c|}{ Industry } \\
\hline & $\begin{array}{c}\text { Inicial } \\
\mathrm{n}=1496\end{array}$ & $\begin{array}{c}\text { Final } \\
n=1496\end{array}$ & $\begin{array}{c}\text { MSBs } \\
n=1185\end{array}$ & $\begin{array}{l}\text { MLCs } \\
\mathrm{n}=311\end{array}$ & $\begin{array}{l}\text { MAN } \\
\mathrm{n}=549\end{array}$ & $\begin{array}{l}\text { COM. } \\
n=461\end{array}$ & $\begin{array}{c}\text { SER } \\
\mathrm{n}=486\end{array}$ \\
\hline Chi-square $\left(\mathrm{X}^{2}\right)$ & 4495.9 & 2189.8 & 390.4 & 377.7 & 451.5 & 207.8 & 154.7 \\
\hline $\begin{array}{l}\text { Degree of freedom } \\
\text { (DF) }\end{array}$ & 204 & 156 & 26 & 26 & 26 & 26 & 26 \\
\hline $\begin{array}{l}\text { Chi-square divided } \\
\text { by the Degree of } \\
\text { freedom }\left(\mathrm{X}^{2} / \mathrm{DF}\right)\end{array}$ & 22.0 & 14.0 & 15.0 & 14.5 & 17.4 & 8.0 & 6.0 \\
\hline Probability level & 0.000 & 0.000 & 0.000 & 0.000 & 0.000 & 0.000 & 0.000 \\
\hline CFI & 0.866 & 0.937 & 0.954 & 0.874 & 0.899 & 0.946 & 0.959 \\
\hline NFI & 0.861 & 0.932 & 0.951 & 0.867 & 0.894 & 0.939 & 0.951 \\
\hline GFI & 0.895 & 0.934 & 0.950 & 0.882 & 0.906 & 0.930 & 0.948 \\
\hline AGFI & 0.830 & 0.861 & 0.894 & 0.750 & 0.800 & 0.852 & 0.889 \\
\hline RMSEA & 0.069 & 0.054 & 0.109 & 0.209 & 0.173 & 0.123 & 0.101 \\
\hline RMR & 0.800 & 0.071 & 0.058 & 0.093 & 0.078 & 0.074 & 0.055 \\
\hline ECVI & 1.059 & 0.566 & 0.379 & 1.406 & 0.930 & 0.578 & 0.439 \\
\hline Cronbach's Alpha & \multicolumn{2}{|c|}{0.862} & 0.844 & 0.888 & 0.865 & 0.843 & 0.863 \\
\hline $\mathrm{KMO}^{*}$ & \multicolumn{2}{|c|}{0.725} & 0.714 & 0.630 & 0.670 & 0.698 & 0.763 \\
\hline $\begin{array}{l}\text { Bartlett's Test of Sphe- } \\
\text { ricity* }\end{array}$ & \multicolumn{2}{|c|}{10709.2} & 7877.5 & 2800.7 & 4232.1 & 3392.9 & 3159.1 \\
\hline $\begin{array}{l}\text { Average Variance Ex- } \\
\text { tracted (AVE) }\end{array}$ & \multicolumn{7}{|c|}{0.749} \\
\hline Composite Reliability & \multicolumn{7}{|c|}{0.967} \\
\hline
\end{tabular}

* Significance level $\mathrm{p}<0.001$.

Table 6. Hypothesis Test (covariance and correlation) - Final Integrated Model

\begin{tabular}{|c|c|c|c|c|c|c|c|}
\hline Construtos & & & $\begin{array}{l}\text { Standardized } \\
\text { Coefficient } \\
\text { (SC) }\end{array}$ & $\begin{array}{l}\text { Standard De- } \\
\text { viation (SD) }\end{array}$ & $\begin{array}{c}\text { Critical } \\
\text { Ratio }(\mathrm{CR})\end{array}$ & $\begin{array}{c}\text { Estimate Coe- } \\
\text { fficient (EC) }\end{array}$ & $\mathrm{p}$ \\
\hline $\begin{array}{l}\text { Organizational } \\
\text { Performance }\end{array}$ & $<---$ & $\begin{array}{l}\text { Competitiva } \\
\text { Sustentável } \\
\text { Vantagem }\end{array}$ & 13,809 & 0,031 & 13,809 & 0,422 & $* * *$ \\
\hline
\end{tabular}

*** Significance level $\mathrm{p}<0.001$. 


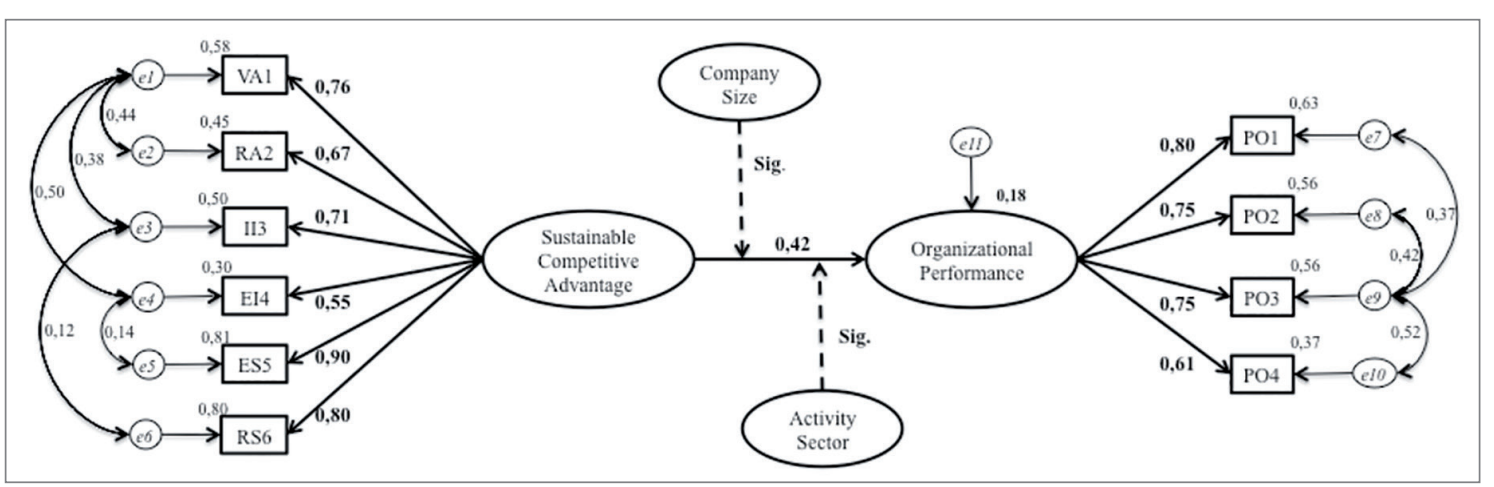

Figure 2. Final Integrated Model - Standardized Regression Weights.

sense, the managerial implications of this research are focused on two aspects: i) the RBV with VA1, RA2, II3 and EI4 attributes is able to generate competitive advantage, which results in a higher performance; ii) in RBV, one must consider ES5 and RS6 attributes, which characterize Corporate Social Responsibility (CSR), and also extend the organization competitive capacity and performance. This statement is based on the results which confirmed the $\mathrm{H} 1$ and $\mathrm{H} 3$ hypotheses.

Additional complementary data are that $21.1 \%$ (303 companies) claim to possess RBV and CSR, confirmed by the replies equal to/greater than 3 on the Likert scale, in all matters of RBV/CSR (VA1, RA2, II3 and EI4, ES5, RS6), and of these, 103 companies also claim to possess higher performance, as noted by the answers of equal to/ greater than 3 in the performance variables (PO1, PO2, PO3, PO4). These data reinforce the importance, when forwarded to managers of organizations, in the search to identify strategic resources that have the attributes presented by Barney (1991a; 1991b) and the environmental and social responsibility advocated by the Ethos Institute (2013), Gri (2013) and Severo et al. (2015).

Statistical evidence, obtained through applying AFA, through the SEM methodology, allows managers to find attributes of resources for performance improvement, as well as provide the scientific community with a framework for resource characteristic analysis that can lead to sustainable competitive advantage. Other academic contributions are the environmental sustainability and social responsibility attributes for the RBV, which increase the importance of research done by Lo and Sheu (2007), Ghoul et al. (2011), and Severo et al. (2015), reaffirming that these attributes are drivers of profitability, and improving social welfare and the environment.

The intensity of the relationship between the constructs of sustainable competitive advantage and organizational performance is evident when analyzing the results of SC and CE of the general-integrated model. However, there is a significant difference between the respondents of the different-sized enterprises, emphasizing that the micro/ small companies have a positive relationship ( $\mathrm{SC}$ and $\mathrm{CE}$ ) between the constructs, but these are inferior to the results presented by medium/large enterprises. These results are expected, since larger companies have financial and technical resources that allow a better use of what is available to increase performance results. In this sense, this paper contributes to the academic research, confirming the need to consider the moderating variable of intensity in the relationships of cause and consequence.

The results show that the Sustainable Competitive Advantage construct is an important antecedent of organizational performance, because this shows fundamental attributes that organizations need to achieve positive economic consequences. In this 
BBR

14,3

sense, the managerial implications of this research are focused on two aspects: i) the RBV with VA1, RA2, II3 and EI4 attributes is able to generate competitive advantage, which results in a higher performance; ii) in RBV, one must consider ES5 and RS6 attributes, which characterize Corporate Social Responsibility (CSR) and also extend the organization competitive capacity and performance. This statement is based on the results which confirmed the $\mathrm{H} 1$ and $\mathrm{H} 2$ hypotheses.

\section{CONCLUSION}

The main contribution of this study is related to the advancement of science in business administration, expansion of academic studies and the support of managerial decisions. In this sense, the following can be highlighted:

a) contributions to the advancement of science through the realization of an empirical research that conducts tests of theoretical precepts discussed by different researchers on the topic of sustainable competitive advantage by using the theories of Resource-Based View (VBR). Note that this research adds new factors to VBR, considering the need to include the characteristics of strategic resources, the social responsibility elements and environmental sustainability that have been tested and proved to be statistically significant, which allows science to promote new studies;

b) the academic contributions of this research are related to the framework developed for this study, which allows researchers to analyze the sustainable competitive advantage and the organizational performance in different companies, with the increase of the characteristics of social and environmental responsibility. This study can serve as a basis for further research in other countries and in different areas of activity.

c) this study provides management contributions related to provision of results, and could show that the company performance can be obtained with the use of strategic resources and that there is no need to include the environmental and social precepts in the search for competitive advantage to improve the economic success of the organization.

This study presents limitations to generalizing the results to different realities, because, though it included a significant number of respondents, it cannot be the only parameter of managerial decision-making in identifying attributes of strategic resources. Thus, a new research for other contexts using this framework for data analysis is recommended. Another limitation of this study refers to the use of theoretical basis which supports the research, since we used an array of important works that do not abridge the scientifical knowledge on Administration in relation to the organizational strategies.

\section{REFERENCES}

AGAFONOW, A. Toward a positive theory of social entrepreneurship on maximizing versus satisficing value capture. Journal of Business Ethics, v. 125, n. 4, p. 709-713, 2014.

AGRAWAL, A. Common property institutions and sustainable governance of resources. World Development, v. 24, n. 3, p. 347-364. 2001.

ARAUJO, L. M.; DUBOIS, A.; GADDE, L. E. The multiple boundaries of the firm. Journal of Management Studies, v. 40, n. 5, 1255-1271, 2003.

ATTIG, N.; EL GHOUL, S.; GUEDHAMI, O.; SUH, J. Corporate Social Responsibility and Credit Ratings. Journal of Business Ethics, v. 117, n. 4, p. 679-694, 2013. 
AVERMAETE, T.; VIANE, J.; MORGAN, E. J.; PITTS, E.; CRAWFORD, N.; MAHON, D. Determinants of product and process innovation in small food manufacturing firms. Trends in Food Science \& Technology, v.15, n. 10, 474-483, 2004.

BAKER, N. A.; NASER, K. Empirical evidence on corporate social disclosure (CSD) practices in Jordan. International Journal of Commerce and Management, v. 10, n. 3-4, p. 18-34, 2000.

BARNEY, J. B. The resource-based model of the firm: origins, implications, and prospects. Journal of Management, v. 17, n. 1, p. 97-98, 1991a.

BARNEY, J. B. Firm resources and sustained competitive advantage. Journal of Management,v. 17, n. 1, p. 99-120, $1991 \mathrm{~b}$.

BESANKO, D.; DRANOVE, D.; SHANLEY, M.; SCHAEFER, S. Economics of strategy. 6 ed. Hoboken: Wiley, 2013.

BYRNE, B. M. Structural equation modeling with AMOS: basic concepts, applications and programming. 2 ed. New York: Taylor \& Francis Group, 2010.

CARROLL, A. Corporate social responsibility: evolution of a definitional construct. Business Society,v. 38, n. 3, p. 268-295, 1999.

CAVES, R. E. Economic analysis and the quest for competitive advantage. The American Economic Review,v. 74, n. 2, p. 127-132, 1984.

CHENHALL, R. H.; LANGFIELD-SMITH, K. Multiple perspectives of performance measures. European Management Journal, v. 25, n. 4, p. 266-282, 2007.

DE GUIMARÃES, J. C. F.; SEVERO, E. A.; DORION, E. C. H. Cleaner production and environmental sustainability: multiple case from serragaúcha-Brazil. Espacios (Caracas). v. 35, n. 4, p. 8, 2014.

DORION, E. C. H.; GUIMARÃES, J. C. F.; SEVERO, E. A.; REIS, Z. C.; PRODANOV, C. C.; OLEA, P. M.; NODARI, C. H. Innovation and production management through a just in sequence strategy in a multinational brazilian metal-mechanic industry. Australian Journal of Basic and Applied Sciences, v. 9, n. 2, p. 100-107, 2015.

ELKIngtON, J. Cannibals with Forks: The Triple Bottom Line of 21st Century Business. Oxford: Capstone Publishing, 1997.

EKINS, P.; SIMON, S.; DEUTSCH, L.; FOLKE, C.; DE GROOT, R. A framework for the practical application of the concepts of critical natural capital and strong sustainability. EcologicalEconomics, v. 44, n. 2-3, p.165-185, 2003.

FIERGS - Federação das Indústrias do Estado do Rio Grande do Sul. Retrieved from http://www.fiergs. org.br Accessed on 6th March 2013.

FECOMERCIO-RS - Federação do Comércio de Bens e de Serviços do Estado do Rio Grande do Sul. Retrieved from http://fecomercio-rs.org.br Accessed on 5th March 2013.

GARENGO, P.; BIAZZO, S.; BITITCI, U. S. Performance measurement systems in SMEs: a review for a research agenda. International Journal of Management Reviews, v. 7, n. 1, p. 25-47. 2005.

GHOUL, S. E.; GUEDHAMI, O.; KWOK, C. C. Y.; MISHRA, D. R. Does corporate social responsibility affect the cost of capital? Journal of Banking \& Finance, v. 35, n. 9, p. 2388-2406, 2011.

GONZÁLEZ-BENITO, J. G.; GONZÁLEZ-BENITO, O. G. A review of determinant factors of environmental proactivity. Business Strategy and the Environment, v.15, p. 87-102, 2006.

GOLINI, R.; LONGONI A.; CAGLIANO, R. Developing sustainability in global manufacturing networks: the role of site competence on sustainability performance. International Journal Production Economics, v. 147(Part B), p. 448-459, 2014.

GRI - Global Reporting Initiative. Index 2013. Retrieved from https:/www.globalreporting.org/resourcelibrary/Portuguese-G3-Reporting-Guidelines.pdf Accessed on 4th May 2013.

GUIMARÃES, J. C. F.; SEVERO, E. A.; DORION, E. C. H.; OLEA, P. M. Attributes for sustainable competitive advantage of firms in the global market. Australian Journal of Basic and Applied Sciences, v. 9, n. 7, p. 459-468, 2015.

HOGAN, S. J.; COOTE, L. V. Organizational culture, innovation, and performance: a test of Scheins model. Journal of Business Research, v. 67, p. 1609-1621, 2014.

HAIR JR., J. F.; BLACK, W. C.; BARDIN, B. J.; ANDERSON, R. E. Multivariate data analysis. 7 ed. New Jersey: Prentice Hall, 2007.

INSTITUTO ETHOS. Indicadores Ethos 2a Geração, 2013. Retrieved from http://www3.ethos.org.br/ wp-content/uploads/2013/07/IndicadoresEthos_2013_PORT.pd Accessed on 6th June 2013.

KLINE, R. B. Principles and practice of structural equation modeling. 2 ed. New York: The Guilford Press, 2005. 
BBR

14,3

KIM, K. H.; JEON, B. J.; JUNG, H. S.; LU, W.; JONES, J. Effective employment brand equity through sustainable competitive advantage, marketing strategy, and corporate image. Journal of Business Research, v. 65, p. 1612-1617, 2012.

KOLK, A. Trends in sustainability reporting by the Fortune Global 250. Business Strategy and the Environment, v. 12, n. 5, p. 279-291, 2003.

KUASIRIKUN, N.; SHERER, M. Corporate social accounting disclosure in Thailand. Accounting, Auditing \& Accountability Journal, v. 17, n. 4, p. 629-660, 2004.

LIN, Y.; WU, L.Y. Exploring the role of dynamic capabilities in firm performance under the resourcebased view framework. Journal of Business Research, v. 67, p. 407-413, 2014.

LO, S.; SHEU, H. Is corporate sustainability a value-increasing strategy for business? Corporate Governance, v. 15, n. 2, p. 345-358, 2007.

MAKADOK, R. Toward a synthesis of the resource-based and dynamic-capability views of rent creation. Strategic Management Journal,v. 22, p. 387-401, 2001.

MARDIA, K. V. The effect of non-normality on some multivariate tests and robustness to non-normality in the linear model. Biometrika, v. 58, n. 1, p.105-121, 1971.

MARÔCO, J. Análise de Equações Estruturais: fundamentos teóricos, softwares \&aplicações. Lisboa: PSE, 2010.

MERCHANT, K. A. Measuring general managers performances: market, accounting and combinationof-measures systems. Accounting, Auditing \& Accountability Journal, v. 19, n. 6, p. 893-917, 2006.

MONEVA, J. M.; LIRIO, J. M. R.; TORRES, M. J. M. The corporate stakeholder commitment and social and financial performance. Industrial Management \& Data Systems, v. 107, n. 1, p. 84-102, 2007.

NEELY, A.; GREGORY, M.; PLATTS, K. Performance measurement system design: a literature review and research agenda. International Journal of Operations \& Production Management, v. 25, n. 12, p.1228-1263, 2005.

NIEMEIJER, D. Developing indicators for environmental policy: data-driven and theory-driven approaches examined by example. Environmental Science and Policy, v. 5, n. 2, p. 91-103, 2004.

PALADINO, A. Investigating the drivers of innovation and new product success: a comparison of strategic orientations. Journal of Product Innovation Management, v. 24, p. 534-553, 2007.

PETERAF, M. A. The cornerstones of competitive advantage: a resource based view. Strategic Management Journal, v. 14, n. 3, 179-191, 1993.

PORTER, M. E. Competitive strategy: techniques for analyzing industries and competitors. New York: Free Press, 1980.

PORTER, M. E. Towards a dynamic theory of strategy. Strategic Management Journal,v. 12, p. 95-117, 1991.

PORTER, M. E.; KRAMER, M. R. Philanthropys new agenda: creating value. Harvard Business Review, p. $121-130,1999$.

ORLITZKY, M., SCHMIDT, F. L.; RYNES, S. L. Corporate social and financial performance: a meta-analysis. Organization Studies, v. 24, n. 3, p. 403-441, 2003.

ROY, M.-J.; BOIRAL, O.; LAGACÉ, D. Environmental commitment and manufacturing excellence: a comparative study within Canadian industry. Business Strategy and the Environment, v. 10, n.5, p. 257-268, 2001.

SEVERO, E. A.; GUIMARÃES, J. C. F.; DORION, E. C. H.; NODARI, C. H. Cleaner production, environmental sustainability and organizational performance: an empirical study in the Brazilian metal-mechanic industry. Journal of Cleaner Production, v. 96, p. 118-125. 2015.

SHAHIN, A.; MAHBOD, M. A. Prioritization of key performance indicators: an integration of analytical hierarchy process and goal setting. International Journal of Productivity and Performance Management, v. 56, n. 3, p. 226-240, 2007.

SHARMA, S.; HENRIQUES, I. Stakeholder influences on sustainability practices in the Canadian forest products industry. Strategic Management Journal, v. 26, n. 2, p.159-180, 1995.

SURROCA, J.; TRIBÓ J. A.; WADDOCK, S. Corporate responsibility and financial performance: the role of intangible resources. Strategic Management Journal, v. 31, n. 5, p. 463-490, 2010.

TANAKA, J. S. Multifaceted conceptions on fit in structural equations modeling. In: K. A. Bollen, and J. S. Long (Eds.). Testing structural equation models. Newbury Park: Sage, p. 10-39, 1993.

TEECE, D. J.; PISANO, G.; SHUEN, A. Dynamic capabilities and strategic management. Strategic Management Journal, v. 18, n. 7, 509-533, 1997.

TRAILL, B.; MEULENBERG, M. Innovation in the Food Industry. Agribusiness, v.18, n. 1, p. 1-21, 2002 . 
TRIGUERO, A.; CÓRCOLES, D.; CUERVA, M. C. Differences in innovation between food and manufacturing firms: An analysis of persistence. Agribusiness, v. 29, n. 3, p. 273-292, 2013.

TUKKER A. Eight types of product-service system: eight ways to sustainability? experiences from suspronet. Business Strategy and the Environment, v. 13, n. 4, p. 246-260, 2004.

VAN BOMMEL, H. W. M. A conceptual framework for analyzing sustainability strategies in industrial supply networks from an innovation perspective. Journal of Cleaner Production, v. 19, p. 895-904, 2011. 